\section{MICROBIAL SURFACTANTS: CLASSIFICATIONS, PROPERTIES, RECOVERY, AND APPLICATIONS}

\author{
Nurazeerah Khamisa, Ainihayati Abdul Rahima,b*, Noor Azlina \\ Ibrahima,b , Khomaizon Abdul Kadir Pahirul Zamanc
}

aDepartment of Bio and Natural Resources Technology, Faculty of Bioengineering and Technology, Universiti Malaysia Kelantan, Jeli Campus, 17600 Jeli, Kelantan, Malaysia

bAdvanced Industrial Biotechnology Cluster, Universiti Malaysia Kelantan, Malaysia

cFaculty of Agro Based Industry, Universiti Malaysia Kelantan, Jeli Campus, 17600 Jeli, Kelantan, Malaysia
Article history

Received

21 January 2021

Received in revised form

8 December 2021

Accepted

11 January 2022

Published Online

21 February 2022

${ }^{*}$ Corresponding author ainihayati@umk.edu.my

\begin{abstract}
Surface-active agents or surfactants are amphiphilic compounds derived naturally or chemically synthesized. Natural surfactants or so-called biosurfactants can be obtained from bacteria, yeasts, and fungi as well as plants. Due to their hydrophilic and hydrophobic molecules, biosurfactants offer the ability to reduce surface or interfacial tension and create microemulsion between aqueous and organic phases. Many studies have suggested biosurfactants as a better substitution to chemical surfactants since they are more environment friendly, biocompatible, and has lower toxicity. This review article is provided to introduce some general information regarding microbial-derived biosurfactants including five main classes of biosurfactants and several distinctive properties that confer them as promising surface-active agents. Due to their diverse molecular structures, biosurfactants have been applied in various applications. Thus, several common biosurfactant recovery methods are discussed and examples of biosurfactant applications in hydrocarbon removal as well as in industrial processing are highlighted.
\end{abstract}

Keywords: Biosurfactants, emulsification, hydrocarbon, recovery, surface tension

\begin{abstract}
Abstrak
Agen permukaan aktif atau surfaktan ialah komponen ampifilik yang diperolehi secara semulajadi atau sintesis kimia. Surfaktan semulajadi atau juga dikenali sebagai biosurfaktan boleh didapati daripada bakteria, yis, fungi dan tumbuhtumbuhan. Disebabkan oleh molekul hidrofilik dan hidrofobik, biosurfaktan menawarkan kebolehan untuk mengurangkan tegangan permukaan atau tegangan antara permukaan, dan mencipta mikroemulsi di antara fasa larutan air dan organik. Banyak kajian telah mencadangkan biosurfaktan sebagai penggantian yang lebih baik untuk surfaktan kimia kerana biosurfaktan lebih mesra alam, lebih biokeserasian dan rendah ketoksikan. Kajian ulasan ini disediakan untuk memperkenalkan beberapa informasi secara umum berkenaan biosurfaktan daripada mikrob termasuk lima kelas utama biosurfaktan dan beberapa ciri berbeza yang menjadikan mereka agen aktif permukaan yang bagus. Disebabkan oleh struktur molekul yang pelbagai, biosurfaktan telah digunakan dalam pelbagai kegunaan. Oleh itu, beberapa kaedah pengekstrakan dibincangkan dan contoh kegunaan biosurfaktan dalam penghapusan hidrokarbon dan proses industri diketengahkan.
\end{abstract}

Kata kunci: Biosurfaktan, hidrokarbon, pengekstrakan, pengemulsian, tegangan permukaan

(C) 2022 Penerbit UTM Press. All rights reserved

\subsection{INTRODUCTION}

Surface-active agents (surfactants) are amphiphilic compounds comprised of both hydrophilic (polar) and hydrophobic (non-polar) portions in the structure. Surfactants are important for their ability to reduce surface or interfacial tension as well as to trigger emulsifying activity between two immiscible phases, conferring them with essential roles in many applications such as bioremediation, oil and 
petroleum industries, food processing, laundry and detergent, cosmetics, medical and pharmaceuticals, and agriculture as wetting agents, foaming agents, emulsifiers, stabilisers, antiadhesive agents, and antimicrobial agents [1-3]. Surfactants can be derived either from chemical synthesis or natural synthesis. Chemical surfactants are commonly distinguished according to their polar portion and the dissociation level in the water. Their groups include anionic, cationic, non-ionic, or zwitterionic, based on the ionic charge of the hydrophilic portion [2]. Nonpolar parts of chemical surfactants are commonly comprised of paraffin, olefins, alkylbenzenes, alcohols, and alkylphenols. Meanwhile, the polar parts that determine which group the surfactants are classified into can be sulphonate, sulphate, carboxylate group, polyoxyethylene, polyoxypropylene, or polyol derivatives [4]. Meanwhile, biosurfactants that are mainly produced by microorganisms can be differentiated based on microbial origins and chemical composition. Two main categories of biosurfactants are low molecular weight (glycolipids, lipopeptides, and phospholipids) and high molecular weight (polymeric compounds and particulate biosurfactants) with molecular sizes of 1 to $2 \mathrm{kDa}$ and larger than $1 \mathrm{MDa}$, respectively $[5,6]$. The hydrophobic parts of biosurfactants are usually saturated or unsaturated fatty acids, hydroxy fatty acids, or fatty alcohols. Meanwhile, the polar parts might consist of carbohydrates, polar peptides or acids, or small hydroxyl, phosphate, or carboxyl groups [7].

The main disadvantage of surfactants is that they are made from long-established chemical surfactants, which have some drawbacks. They are less degradable by microorganisms in the environment, resulting in longer persistence in the environment and the potential for harm to the microbiota and aquatic ecosystem [8]. Chemical surfactants such as sodium laureth sulphate, ammonium laureth sulphate, or alkyl ether phosphates that are abundantly applied in daily care products such as cosmetics and cleaning agents can irritate the sensitive skin and might contribute to dermatological problems. Besides, the production of chemical surfactants that particularly come from petroleum can contribute to the depletion of that non-renewable resource. Contrarily, biosurfactants are recognised to be eco-friendly, biodegradable, and lower in toxicity, which instigates them to be extensively studied as a replacement for chemical surfactants [9, 10]. In fact, these natural surfactants can be feasibly synthesised from cheap raw materials such as hydrocarbon-based oils and agricultural-based oil effluent [11]. Due to these advantages, some biosurfactants such as rhamnolipid, MELs, sophorolipid, and emulsan have been commercialised as dispersive agents or emulsifiers in oil products, oil recovery, and cosmetics $[3,4,12,13]$.
Due to the significance of biosurfactants, this review article is written to introduce some basic information on classifications, properties, and recovery processes of microbial biosurfactants, with an emphasis on applications in hydrocarbon removal and industrial processing.

\subsection{CLASSIFICATION OF BIOSURFACTANTS}

\subsection{Glycolipids}

Glycolipids are among the most studied biosurfactants, comprising either mono- or disaccharide carbohydrates bound to long chains of aliphatic acids or hydroxy-aliphatic acids [9]. Four main biosurfactants in this class are rhamnolipids that are mainly produced by Pseudomonas spp., sophorolipids from Candida bombicola and Candida apicola, trehalolipids that are secreted by Rhodococcus sp., mannosylerythritol lipids (MEL) from basidiomycetous yeasts Pseudozyma (Pseudozyma rugulosa, $P$. aphidis, and $P$. antarctica), and by the Ustilago fungus species [14].

\subsection{Lipopeptides}

Based on the chemical structures, lipopeptides can be divided into linear and cyclic lipopeptides. This type of biosurfactant consists of lipids attached to polypeptide chains $[15,16]$. Bacillus subtilis mainly produces surfactin and iturin, while Bacillus licheniformis is the primary producer of lichenysin [1719]. Other microorganisms that produce lipopeptide biosurfactants include Pseudomonas, Streptomyces, Aspergillus, Serratia, and Actinoplanes [15]. Lipopeptide biosurfactants are known for their properties as antimicrobial agents [20].

\subsection{Phospholipids and Fatty Acids}

Some microorganisms, such as bacteria from the genera Nocardia, Thiobacillus, Candida, Acinetobacter, Pseudomonas, Micrococcus, Mycococcus, Penicillium, and Aspergillus, secrete phospholipids and fatty acids when grown on nalkane as a carbon source [9]. The phospholipid component in a cell membrane is phosphatidylethanolamine, which is involved in surface activity. This rich vesicle is usually produced by Acinetobacter species and Rhodococcus erythropolis when grown on n-alkane as the carbon substrate for their growth $[16,21,22]$.

\subsection{Polymeric Biosurfactants}

Polymeric biosurfactants are formed by the combination of several compounds with different chemical structures, such as heteropolysaccharides, exopolysaccharides, carbohydrate-lipid-protein mixtures, and other polysaccharide-protein 
complexes $[5,16]$. The most common and widely investigated polymeric biosurfactants are emulsan, alasan, and liposan, produced by A. calcoaceticus, Acinetobacter radioresistens, and Candida lipolytica, respectively $\quad[9,21,23]$. Meanwhile, exopolysaccharide, or EPS, is another essential extracellular polymer which is classified into carbohydrate-lipid-protein complexes or glycolipopeptide groups secreted by microorganisms such as Alcaligenes, Halomonas, Antarctobacter, Pseudomonas, and Planococcus [5,23].

\subsection{Particulate Biosurfactants}

Some biosurfactants are present in the form of extracellular membrane vesicles that function in surface activity in most of the hydrocarbon degradation processes and pathogenicity of bacteria [24]. For example, Acinetobacter spp. produced vesicles composed of protein, phospholipid, and lipopolysaccharides with diameters and buoyant densities of 20 to $50 \mathrm{~nm}$ and $1.158 \mathrm{~g} / \mathrm{cm} 3$, respectively [22]. Furthermore, some microbial cells have high cell surface hydrophobicity and a strong affinity towards hydrocarbons, making them cell-bound biosurfactants. These types of biosurfactants are usually produced by hydrocarbondegrading microorganisms and the Cyanobacteria species [25].

\subsection{PROPERTIES OF BIOSURFACTANT}

\subsection{Surface and Interfacial Tension Activity}

Good biosurfactants possess the ability to reduce the surface tension of water from $72 \mathrm{mN} / \mathrm{m}$ to less than 30 $\mathrm{mN} / \mathrm{m}$ and the interfacial tension of $\mathrm{n}$-hexadecane from $40 \mathrm{mN} / \mathrm{m}$ to $1 \mathrm{mN} / \mathrm{m}$ [18,22]. Surfactin and rhamnolipids produced by $B$. subtilis and Pseudomonas aeruginosa, respectively, are examples of biosurfactants that can reduce water surface tension from $27 \mathrm{mN} / \mathrm{m}$ to $25 \mathrm{mN} / \mathrm{m}$ and interfacial tension of hexadecane to less than 1 $\mathrm{mN} / \mathrm{m}[18,26]$.

\subsection{Emulsification and Demulsification Activity}

Biosurfactants are involved in emulsification by lowering the interfacial tension between organic and aqueous phases, allowing interfacial mass exchange at the surface, thus leading to solubilisation by increasing the permeation of organic compounds into the aqueous solution through the formation of micelles [27]. Emulsan produced by Acinetobacter, rhamnolipid secreted by Pseudomonas spp., and some biosurfactants from Arthrobacter and Cyanobacterium are common bio-emulsifiers used in industrial applications [28]. On the contrary, demulsification is an essential mechanism in separating water molecules from the oil phase in water-in-oil (W/O) emulsions, which have become a common problem in the oil industry. Nocardia amarae, Corynebacterium petrophilum, Rhodococcus aurantiacus, B. subtilis, Micrococcus sp., Torulopsis bombicola, A. calcoaceticus, Alteromonas, Rhodococcus, Alcaligenes, and Aeromonas are among natural de-emulsifiers that can break emulsions with their cell-bound or extracellular biosurfactants [29].

3.3 Temperature, pH, Salinity, and Ionic Strength Tolerance

Another property of biosurfactants is their tolerance to a variety of temperature, $\mathrm{pH}$, salinity, and ionic strength. For example, lichenysin produced by $B$. licheniformis is resistant to temperature as high as 50 ${ }^{\circ} \mathrm{C}$, $\mathrm{pH}$ range between 4.5 and 9.0, and concentrations of $\mathrm{NaCl}$ and $\mathrm{Ca}$ up to $50 \mathrm{~g} / \mathrm{L}$ and 25 $\mathrm{g} / \mathrm{L}[16,26,28]$. Alasan, a bio-emulsifier from $A$. radioresistens strain KA53, can tolerate strong alkaline conditions and high temperatures between 60 and $90{ }^{\circ} \mathrm{C}$ [28]. Meanwhile, a biosurfactant from Arthrobacter protophormiae is thermostable to the range of temperature from 30 to $100^{\circ} \mathrm{C}$ and can survive in extreme acidic and alkaline conditions $(\mathrm{pH}$ 2 to 12) [30].

\subsection{Low Toxicity}

Biosurfactants have been proven to have lower toxicity or non-toxic properties that give them advantages in many applications. For instance, the eco-toxicity and phytotoxicity tests of $0.25 \%$ and $0.5 \%$ concentrations of biosurfactant from Candida tropicalis showed no toxic effect towards Artemia salina (brine shrimp), while germination indices of wild cabbage (Brassica oleracea) were $66 \%$ and $56 \%$, respectively, indicating no inhibitory effects on the seeds and root growth [31]. It was supported by biosurfactants from Bacillus subtilis that showed no toxicity effects on the growth of lettuce (Lactuca sativa) [32], which proposed them as good agents for bioremediation. In another study, biosurfactants from B. subtilis ATCC 6633 showed low toxicity to cell membranes, enabling them to be the appropriate candidate in drug formulation [33]. Meanwhile, surfactin from Bacillus subtilis HSO121, as has been studied by Fei et al. (2019), was suitable to be included in detergent formulations since it showed less toxicity in acute dermal irritation and acute oral toxicity ( $\mathrm{LD}_{50}$ and $\mathrm{LC}_{50}$ ) with values of more than 5000 $\mathrm{mg} / \mathrm{kg}$ and $1000 \mathrm{mg} / \mathrm{kg}$, respectively.

\subsection{Higher Specificity}

Biosurfactants demonstrate specific actions that make them essential for applications such as the detoxification of different pollutants. This property is demonstrated by the $92 \%$ removal of heavy metal chromium in 36 hours of leaching by di-rhamnolipid of $P$. aeruginosa BS2 compared to tap water [35]. In 
addition, trehalolipid produced by Nocardia mediterranei showed a higher degradation of the pesticide Chlorpyrifos compared to Methyl Parathion and Dichlorvos in a comparative study of degradation towards different organophosphates [36]. The specificity of biosurfactants has also assisted in obtaining targeted biosurfactants by altering the substrate in the growth media. For instance, a mixture of surfactin, iturin, and fengycin was produced by Bacillus amylofaciensstrain AR2 in a medium supplemented with dextrose, sucrose, and glycerol. However, only iturin was produced by the same bacteria in the presence of maltose, lactose, and sorbitol [37]. Meanwhile, P. aeruginosa produced rhamnolipids when grown on glycerol and glucose, but lipopeptide was produced when waste cooking oil was used as a carbon substrate [38].

\subsection{Biodegradability}

Biosurfactants are easily degraded by microorganisms as they come from natural sources, making them more compatible with the environment. In a biodegradability test by Feng et al. (2019), lipopeptide produced by B. subtilis HSO121 achieved complete degradation after 3 days compared to the synthetic surfactant sodium dodecyl benzene sulfonate (SDBS). Sophorolipids produced by $C$. bambicola also showed an immediate degradation process after cultivation in some biodegradability tests [6]. Due to their biodegradability properties, which cause less damage to the environment, most biosurfactants are adequate to be used in bioremediation and wastewater treatment. For example, sophorolipids have been used to control blooms of Cochlodinium (marine algae). Besides, biosurfactants from marine microorganisms have aided in the adsorption of poorly soluble polyaromatic hydrocarbons (PAHs) such as phenanthrene on aquatic surfaces [16].

\subsection{Antimicrobial and Antiadhesive Activity}

Glycolipids and lipopeptides are biosurfactants that mainly possess antimicrobial activity. The general mechanism of antimicrobial action is by the intercalation of biosurfactants into the cell membranes, which then destroy the cell membranes by changing their permeabilising effect and leading to cell death [40]. Biosurfactants have antagonistic activities towards bacterial pathogens such as $P$. vulgaris ATCC 27973, V. harveyi ATCC 14126, E. faecalis ATCC 29212, S. epidermidis KCTC 1917, E. coli ATCC 25922, and C. albicans SC5314, which suggests that they are important antimicrobial agents in medical applications [40]. In food processing, biosurfactants are used to inhibit the growth of Listeria monocytogenes, an important food-related pathogen [3]. Meanwhile, the properties of glycolipid and lipopeptide as antifungals make them suitable to be used as biocontrol agents for plant diseases [26].

\subsection{RECOVERY OF BIOSURFACTANT}

The recovery of biosurfactants is determined based on the physiological production (extracellular or cellbound), ionic charge, and solubility of biosurfactants in specific solvents [41, 42]. The recovery process usually involves the combination of several methods, i.e., washing, foam fractionation, precipitation, crystallization, filtration, ultrafiltration, solvent extraction, adsorption, and chromatography [43, 44] as has have been summarized in Figure 1. It begins with the removal of bacterial cells from the medium broth by centrifugation for extracellular biosurfactant or by the addition of lysis reagents such as enzymes and detergents to break down the cells in the case of intracellular biosurfactant. Then, the biosurfactants will be isolated from the fermentation medium by reducing their solubility in the medium solution using alcohols, acids, or salts. Acid precipitation is a favoured method for isolating biosurfactants. In acid precipitation, concentrated hydrochloric acid $(\mathrm{HCl})$ is used to lower the $\mathrm{pH}$ of the supernatant solution by $\mathrm{pH} 2$ to 3. In the acidic condition, polar molecules such as the carboxyl group of rhamnolipids will be protonated, making them less soluble in aqueous solution [44]. One limitation of acid precipitation is that it can also precipitate non-selective elements that have low solubility in acidic conditions, such as extracellular protein, alginic acid, and other metabolites [44]. As a resolution to this matter, other following recovery techniques are required to eliminate the unwanted components. Besides acid precipitation, proteins, lipids, and polysaccharides which are components of biosurfactants can also be extracted by ethanol precipitation, acetone precipitation, and salt precipitation $[41,42,45,46]$. In some cases, precipitation method is sufficient to be used as a sole method to extract crude biosurfactant. In a study by Invally et al., (2019), acid precipitation after biopolymer removal by prior alcohol precipitation is sufficient to extract out the rhamnolipid from the solution. This method was comparable with acid precipitation-solvent extraction, where the solvent extraction after acid precipitation step did not lead to the increment of yield rhamnolipid.

Precipitations are usually followed by centrifugation at $12,000 \mathrm{rpm}$ at $4^{\circ} \mathrm{C}$ for 15 minutes to collect the crude biosurfactants, which will then be further extracted by other methods such as solvent extraction, foam fractionation, and adsorptiondesorption [47]. Solvent extraction is applied based on the polarity charge that influences the dissolution of biosurfactants in different types of solvents [47]. In general principle, polar solutes tend to dissolve in polar solvents, while non-polar solutes are more favourable to dissolving in non-polar solvents. The ratio of hydrophilic and hydrophobic moieties in the structure of biosurfactants will determine the degree of polarity and solubility of the biosurfactants in different solvent solutions. Glycolipids such as 
rhamnolipid and sophorolipid are typically extracted from aqueous solutions by standardised solvent extraction using ethyl acetate $[46,48]$. For instance, the crude sophorolipid from $S$. bambicola grown on glucose and refined, bleached, and deodorised (RBD) palm olein substrate has been successfully recovered by ethyl acetate with a total yield of 53.3 $\mathrm{g} / \mathrm{L}$ [49]. Meanwhile, chloroform-methanol is the most common solvent combination for trehalolipids, lipopeptides, and other high molecular weight compounds extraction $[46,50]$.

By the absorption of the molecules onto air bubbles in the culture medium, foam fractionation is used to separate biosurfactant molecules from the medium. The principle behind this method is that the bubbles that are generated by the aeration system will move up to the top of the liquid surface and turn into the collapsed foams that contain more concentrated surface-active compounds due to the gravity force [51]. The advantages of foam fractionation are that it allows continuous removal of products, prevents the accumulation of products in the media, which can inhibit microbial growth and product formation, and facilitates the extended biosurfactant production in fed-batch and continuous batch fermentation [22]. The efficiency of foam fractionation methods depends on airflow rate, the pore size of the sintered glass disk, foam height, liquid height, initial liquid volume, operation time, and feed flow rate [51]. Sarachat et al., (2010) found that $97 \%$ of the rhamnolipid of Pseudomonas aeruginosa SP 4 has been concentrated and recovered by foam fractionation with operating conditions of $30 \mathrm{ml} / \mathrm{min}$ of flow rate, an initial foam height of $60 \mathrm{~cm}$, a pore size of the sintered glass disc of 160 to $250 \mu \mathrm{m}$ (No.0), an initial liquid volume of $25 \mathrm{~mL}$, and 4 hours of operation time. Meanwhile, trehalolipids from the marine bacterium Rhodococcus sp. PMLO26 were extracted by this method with a $25-58 \%$ recovery [52].

Adsorption-desorption is a common technique used to separate biosurfactants after the process of eliminating heavy metals, enzymes, biological polymers, or oil contaminants by other methods such as membrane separation, chemical precipitation, and ion exchange [51]. This method involves the adsorption and desorption of biosurfactant molecules from hydrophobic polymers such as Amberlite XAD 2 or 16 polystyrene resins or activated carbon $[17,43]$. It was effective to remove proteins, polysaccharides, and peptides from the prepurification stage to obtain surfactin with a purity of up to $88 \%$ and a recovery of up to $95 \%$ on the slightly polar XAD-7 resin [43]. This technique is fast, requiring only one recovery step and results in high-quality purified biosurfactants [47]. This method is governed by several factors such as agitation rate, activated carbon particle size, initial adsorbate concentration, amount of adsorbent, ionic strength, $\mathrm{pH}$, and temperature [17].

As an additional step to obtaining high purity of biosurfactants, polishing techniques are required to eliminate any contaminants. For instance, ultrafiltration (two-step method) is used to purify the lipopeptides and glycolipids in micelles formed above the Critical Micelle Concentration (CMC) [43]. It is usually used as a further purification method to concentrate the biosurfactants after several prior approaches to getting crude (semi-purified) biosurfactants from acid precipitation, foam fractionation, and solvent extraction. Ultrafiltration was first introduced by Mulligan \& Gibbsb (1990) for the recovery of surfactin and rhamnolipid. In the first step (UF-1) of surfactin purification, the surfactin (micelles) and protein are filtered (0.45 $\mu \mathrm{M})$ and recovered as retentate. Then, the solvents such as ethanol or methanol will be added to the retentate and re-filtered in the second step (UF-2). In the presence of ethanol or methanol, the surfactin micelles will be separated into monomers and they will be recovered as permeate. Meanwhile, proteins remain retentate as they form aggregations in ethanol or methanol solvents [17].

Chromatography is another effective technique to purify crude biosurfactants by manipulating the solvent system to migrate the components through the solid phase flowed by the mobile phase according to the non-covalent interaction of components with the column [47]. The separated fractions are analysed by detectors such as refractive index (RI), UV, fluorescent, radiochemical, electrochemical, near-infrared, MS, NMR, and light scattering [47]. Free rhamnose and lipopeptides are common components that are separated by chromatography technique. For example, dirhamnolipid and mono-rhamnolipid from $P$. aeruginosa were completely separated by thin layer chromatography (TLC) technique using aluminium silica gel 60 F254 plates as absorbent material with a fraction ratio of chloroform: methanol: $20 \%$ aqueous acetic acid (65:15:2) solvent system after being extracted by solvents methanol: chloroform: acetone $(1: 1: 1)$ [54]. Meanwhile, the high-speed counter current chromatography with three-phase solvent system composed of $n$-hexane-methyl acetateacetonitrile-water $(2: 2: 2: 5, \quad v / v)$ was efficiently separated a mixture of six rhamnolipids, $\mathrm{RhaC}_{10} \mathrm{C}_{10}(0.73 \mathrm{mg}), \mathrm{RhaC}_{10}(0.51 \mathrm{mg}), \mathrm{Rha}_{2} \mathrm{C}_{10}(0.12$ $\mathrm{mg}$ ), $\operatorname{RhaC}_{10} \mathrm{C}_{12}$ (1.26 mg), $\mathrm{Rha}_{2} \mathrm{C}_{10} \mathrm{C}_{10}(1.03 \mathrm{mg})$, and $\mathrm{Rha}_{2} \mathrm{C}_{10} \mathrm{C}_{12}(0.87 \mathrm{mg})$ with recovery percentage of 96.37, 95.20, 91.25, 84.41, 89.8, and 90.26\%, respectively [55]. After purification stages, biosurfactants can be further characterised afterwards in terms of their molecular and physical structure, molecular mass measurement, and their congeners using several high technology automated analyses such as High Performance Liquid Chromatography (HPLC), Fourier Transform Infra-Red (FT-IR), Nuclear Magnetic Resonance (NMR), Gas Chromatography-Mass Spectrometry (GC-MS), Electrospray Ionization-Mass Spectrometry (ESI-MS) or Scanning Electron Microscope with a combination of Energy Dispersive X-ray (SEM-EDX) $[41,46,47]$. 
Although some of the biosurfactants have achieved the highest level of production and have been successfully commercialised, the biggest challenge in biosurfactant production still comes from the downstream process. Since the concentration of the target product is relatively small, it is quite difficult to purify biosurfactant. The choice of recovery methods is crucial to the effective separation of biosurfactants from the complex mixture of medium, substrates, cells, and other extracellular components [43]. The purity of biosurfactants is required according to their application. For instance, biosurfactants that are produced for food and beverages, medical applications, and pharmaceuticals are required to be lower in toxicity and have a higher purity. Multiple recovery processes and analyses should be conducted for these purposes, resulting in higher investment costs. Another constraint is the loss of yield biosurfactants due to the recovery technique itself. In ultrafiltration, for example, the blockage or fouling of the filter membrane by large molecules such as micelles of biosurfactants and other contaminants can lead to a decrease in yield production [51]. Besides, the conventional methods of biosurfactant recovery commonly involve the usage of organic solvents that can inflict some detrimental outcomes, including the loss of yield in biosurfactant products, loss of biosurfactant activity due to organic solvents, time and cost in the recovery process, and toxic waste in the environment from a large amount of solvent used [51].

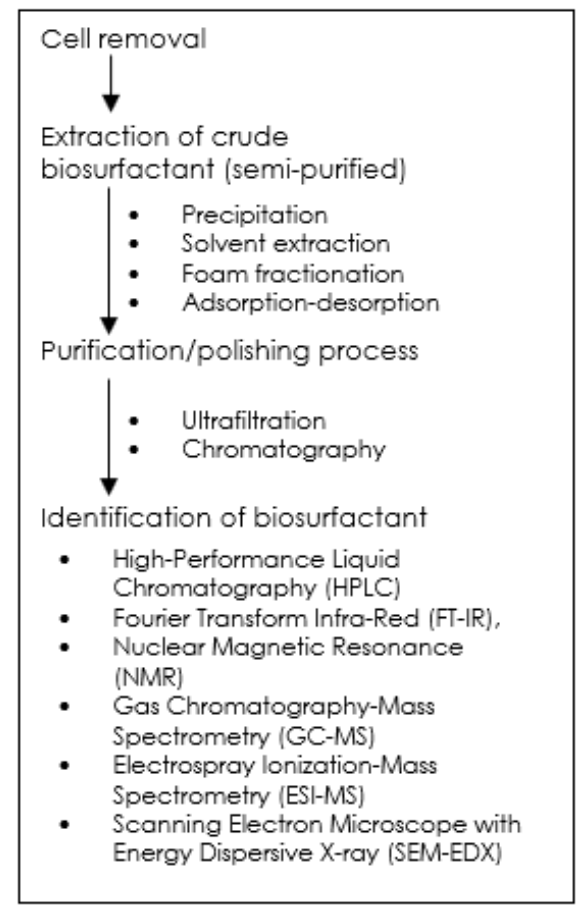

Figure 1 The flowchart of some basic methods for recovery of biosurfactants

\subsection{APPLICATIONS OF BIOSURFACTANT}

\subsection{Hydrocarbon Clean-up Process}

Hydrocarbon contamination is one of the critical factors that contribute to environmental pollution. The sources of hydrocarbon contaminants are accidental oil spills from vehicles on the road, marine-related accidents that cause petroleum oil spills into the sea, pesticide waste that is not properly degraded, and other toxic organic matters. Petroleum hydrocarbons contain aliphatic compounds (n-alkanes or n-alkenes), aromatics (benzene, tolvene, ethylbenzene, and xylenes [BTEX] compounds), resins (naphthenic aromatic hydrocarbons), and asphaltenes, which are carcinogenic and may lead to various health problems such as tumours, cancer, and failure of the nervous system should they enter the body by ingestion of contaminated food or water, or by prolonged skin contact $[35,56]$. Other contaminants commonly present in soils are hydrophobic organic compounds (HOCs) from petroleum and fuel residue, chlorinated compounds in commercial solvents, and pesticides from agricultural waste. Heavy metals such as mercury, chromium, cadmium, lead, arsenic, manganese, nickel, and copper are also toxicants that predominate in soils and sediments. These contaminants are high in hydrophobicity, allowing them to be strongly adsorbed by soil particles and persist longer in the environment [57].

Several approaches have been taken in the process of hydrocarbon contamination clean-up involving physical, chemical, and biological remediation. Bioremediation is the process of removing or detoxifying pollutants using the diverse metabolic capabilities of microorganisms. Bioremediation can be divided into two processes, i.e., in-situ and ex-situ. In situ bioremediation uses techniques such as bio-stimulation, bioventing, injection of hydrogen peroxide, and bioaugmentation. Meanwhile, the ex-situ process involves the excavation of contaminated soil from the ground to be treated elsewhere, which includes techniques like landfarming, composting, biophiles, and bioreactors [56]. Both bioremediation techniques involve biodegradation processes that require the presence of hydrocarbon-degrading microorganisms. Biodegradation is the metabolic activity by microorganisms that neutralises and transforms organic pollutants into non-hazardous and less harmful substances before releasing them into the environment [58]. Biosurfactant producers play essential roles in the degradation of hydrocarbon pollutants. The hydrocarbons from oil are biologically decomposed by microorganisms that use the pollutants as a carbon source for nutrients and energy for growth. As a result, the microorganisms will produce biosurfactants as metabolites, which then enhance the oil dispersion and solubility by emulsification. This mechanism will allow oil particles 
to be degraded by microorganisms into carbon dioxide, water, mineral salts, and gases [59].

Several biosurfactants have been efficiently used in hydrocarbon degradation. Alasan, a bio-emulsifier complex, and BS29 bioemulsans, produced by Gordania spp. strain BS29, are effective in removing crude oil and PAHs from soil [60]. The rhamnolipid produced by $P$. aeruginosa $P a$ can reduce diesel by $58 \%$ in 14 days and degrade a higher carbon number of diesel constituents $\left(\mathrm{C}_{15}\right.$ to $\left.\mathrm{C}_{24}\right)$ [48]. In another study, P.aeruginosa can degrade hydrocarbon components from $\mathrm{C} 12$ to $\mathrm{C} 30$, while Acinetobacter Iwoffii was more effective in degrading $\mathrm{C} 11$ to $\mathrm{C} 17$ hydrocarbon fractions than P.aeruginosa after 48 hours of incubation [61].

The biosurfactant of Bacillus cereus grown in olive oil as a carbon substrate, with sodium nitrate as the best nitrogen source, at an optimum $\mathrm{pH}$ of 7 , and a temperature of $37{ }^{\circ} \mathrm{C}$, showed the maximum degradation of petrol and diesel [62], suggesting its potential in bioremediation. Meanwhile, sophorolipid derived from the yeast Candida bombicola URM 3718, formulated with potassium sorbate, was patented in the Brazilian National Intellectual Property Institute (patent number BR1020140179631) as a commercial dispersant to treat petroleum oil pollutants in the marine environment [63]. However, the hydrocarbon contaminants usually have a lower degradation rate by only a single genus of microorganisms because each microorganism has different genetic characteristics. Therefore, appropriate consortium bacteria have been developed according to their suitability to degrade different groups of hydrocarbons. More information about hydrocarbon degradation by microorganisms in bioremediation can be found in a review article written by Sylvester et al. (2019).

In the oil and petroleum industry, biosurfactants are involved in the oil recovery process, transportation of crude oil, breaking oil field emulsions, and removal of oil residues. Microbial enhanced oil recovery, or MEOR, is a technique to recover oil from low permeability or highly viscous crude oil reservoirs using microorganisms. Several methods have been applied in the MEOR process based on the reduction of interfacial tension and oil viscosity. To produce the desired bio compounds that aid in oil mobilisation, nutrients containing microbes from specific bacteria, such as $P$. aeruginosa and $B$. licheniformis, are injected, as well as a direct injection of biosurfactants [50,64]. These processes are then followed by reservoir repressurisation, reduction of tension or oil viscosity, and movement of oil to produce wells [3]. During the transportation of crude oil from the extraction fields to the refineries, the highly viscous asphaltene residues in crude oil can cause low flowability and problems in the pipelines, such as deposition of asphaltenes and/or paraffin residues and a drop in pressure [10]. These problems can be overcome using bio-emulsifiers that can disperse the oil into smaller droplets and prevent the droplets from coalescing.

The most common emulsion in the oil industry is water-in-oil (W/O) emulsion, also known as "chocolate mousse" or "mousse" [65]. Due to their low interfacial energy, the mixture of two immiscible phases will spontaneously create this type of emulsion. To avoid corrosion and the growth of microorganisms in pipelines and storage tanks, the oil must have a water content of less than 1\% [66]. Therefore, this oil field emulsion is another major problem in the petroleum industry. The W/O emulsion problems can be solved by the demulsification process. Demulsification is the reversible process of emulsification whereby the stable emulsions will be separated into oil and water phases. The conventional methods of the demulsification process are by centrifugation, heat treatment, and chemicals. These processes can be enhanced by the addition of de-emulsifiers. The demulsification of crude oil occurs in three main steps: (a) the replacement of asphaltene (emulsion stabilizer) with biosurfactants in the oil-water interface, (b) flocculation of the dispersed droplets, and (c) coalescence of the water droplets entrapped in micelles [29]. Alcaligenes, Pseudomonas, Bacillus, and Delftia species are examples of biosurfactant producers that exploit the hydrophobic and hydrophilic nature to disrupt the emulsions $[29,67]$.

\subsection{Other Applications of Biosurfactant}

Due to the various properties of biosurfactants, these bio-compounds have been extensively applied as food additives. The important properties of biosurfactants to be used in food processing are their potential as emulsifiers, as well as their antimicrobial and antiadhesive characteristics. The antimicrobial and antiadhesive properties of biosurfactants are important against pathogenic bacteria, yeast, viruses, fungi, and algae [12]. Rhamnolipids, surfactin, and lunasan, which are produced by Pseudomonas spp., Bacillus spp., and the yeast Candida sphaerica UCP0995, can prevent the attachment of food pathogens such as Listeria monocytogenes, Staphylococcus aureus, and Micrococcus luteus on polystyrene surfaces by their antiadhesive activity [1]. Rhamnolipids combine with nisin, a broad-spectrum bacteriocin showing synergetic effects and very efficient at inhibiting food pathogens like $L$. monocytogenes [3]. Furthermore, the dairy probiotic strain Lactobacillus acidophilus has been shown to have potential as a uropathogen growth inhibitor, making it an appropriate candidate for oral application in commercial food products [1]. The biosurfactants are also crucial in controlling the accumulation of fat globules, improving the consistencies of starch and fat-based products, as stabilisers in an aerated system, providing texture, prolonging shelf-life, and modifying rheological properties in the wheat dough [26]. In ice cream and bakery formulations, the use of rhamnolipids improves 
the stability of the dough, volume, texture, flavour, and preservation of the products [16]. Meanwhile, yeasts such as Yarrowia lipolytica, Saccharomyces cerevisiae, and Kluyveromyces lactis have achieved the status of "generally regarded as safe" (GRAS) for their low toxicity properties and suitability in food and pharmaceutical applications [22].

In the laundry and detergent industries, overfoaming is a common problem due to the addition of excess detergent and could interfere with the cleaning process. This problem can be solved using de-foaming agents, and biosurfactants can play a role in reducing foam formation. Some biosurfactants, such as sophorolipids from C. bombicola, have low foaming properties and can be used to enhance oily soil detergency in fabric washing [28]. Biosurfactants remove oil and dirt in washing by increasing the solubility of oil particles by creating emulsions. A study by Bafghi \& Fazaelipoor (2012) showed that rhamnolipids were efficient in removing oil from cotton cloth with the highest percentage (10\%) of the detergent formulation. Besides, washing at a lower temperature will lead to the formation of biofilm due to the accumulation of some microorganisms in the vessels of washing machines. Some biosurfactants can prevent biofilm formation as they possess antiadhesive and antimicrobial properties. The presence of biosurfactants in the laundry detergent formulation may inhibit biofilm formation in waste pipes [14]. Biosurfactants of psychrophilic organisms can also improve the washing performance at cold and freezing temperatures, and this can reduce energy consumption by allowing the laundry process at lower temperatures [69]. Sustainability in alkaline conditions and extreme temperatures are also important factors for biosurfactants to be applied in the detergent industry. These properties were shown by the thermophilic Ochrobactrum intermedium strain MZV101, isolated from hot springs $\left(60^{\circ} \mathrm{C}\right)$. This isolate produced lipase and biosurfactant which remained stable at $\mathrm{pH} 5$ to 13, exhibited emulsification stability at temperatures of $70{ }^{\circ} \mathrm{C}$ to 90 ${ }^{\circ} \mathrm{C}$, and had strong oil removal activity [70].

Biosurfactants in cosmetics and healthcare products have roles as emulsifiers, de-emulsifiers, solubilizers, cleansers, wetting agents, foaming agents, antimicrobial agents, and mediators of enzyme action [22]. Cleaning products (shampoos, conditioners, shower creams, make-up removers, toothpaste, polishes, and denture cleansers), lotions (moisturisers, sunscreens, and face and body lotions), manicure and pedicure products, make-up products (lipsticks and eyeshades), body care regimes (deodorants and antiperspirants), baby products, and body massage accessories are among the dailyused products that require surface-active agents in their formulations [9]. Some synthetic surfactants may cause skin irritation in sensitive users due to the harsh chemical composition in the formulation. For example, linear alkylbenzene sulphonates (LABS) manufactured from alkylbenzene are harmful to the skin and are deemed unsuitable to be included in personal care formulations [71]. Biosurfactants might be a better replacement compound for synthetic surfactants since they are lower in toxicity and gentler on the skin. Studies have suggested that biosurfactants may aid in wound healing; therefore, they may reduce the skin's allergenicity and irritation caused by other ingredients in cosmetic products [14]. The aqueous and oil components can be well mixed by reducing the interfacial tension and emulsification with bio-emulsifiers such as liposan, produced by $C$. lipolytica. This bio-emulsifier can form stable oil-in-water (O/W) emulsions, which are essential in beauty and health care product formulation [22]. The Acinetobacter bacteria also produce biosurfactants that can be applied to personal care products. For example, bio-emulsifiers from A. calcoaceticus in shampoo and soap formulations act effectively against acne and eczema. Besides, lipopolysaccharide from Acinetobacter strains also facilitates bath agents to be more effective in reducing slime and fur in the bathtub and bath furnace [50]. Meanwhile, MEL, a biosurfactant from the glycolipid group, has also been used in cosmetics and has been commercialised by the Japanese companies Toyobo and Kanebo Cosmetics [13].

Most biosurfactants are applied in medical products due to their potential as antimicrobials and antiadhesive agents. B. subtilis is a well-known producer of surfactin, one of the most powerful antimicrobial agents that has been used in the precoating of vinyl urethral catheters to decrease biofilm formation by pathogens such as Salmonella enterica, Salmonella typhimurium, Escherichia coli, and Proteus mirabilis [26]. Surfactin has a broad spectrum of antiviral activity and effectively inactivates herpes and retroviruses, as well as other compact RNA and DNA viruses [22]. B. subtilis strains can also produce a lipopeptide called iturin with antifungal activity. In an experiment, iturin was reported to affect the morphology and structure of the cell membrane of yeasts [22]. Other biosurfactants that can possess antimicrobial properties are MEL produced by $C$. antartica and Kurtzmanomyces spp., rhamnolipids produced by $P$. aeruginosa, and lipopeptides from $B$. licheniformis $[3,20]$. The ability of biosurfactants to act against a wide range of pathogens is also beneficial in drug formulation in pharmaceuticals. The commercial antibiotic, Cubicin, commercialised by Cubist Pharmaceuticals, is an example of a branched cyclic lipopeptide, namely Daptomycin, isolated from streptomyces roseosporus. This antibiotic has been used in the treatment of skin infections caused by pathogens such as $S$. aureus, Streptococcus pneumoniae, Staphylococci, and Enterococci [22]. Biosurfactants also play roles in the pharmaceutical and medical fields, such as inducing cell differentiation in the human cell line HL60 against promyelocytic leukaemia, gene delivery agents, immunological adjuvants, probiotic agents, anti- 
tumour, anti-inflammatory, haemolytic, and chelating agents $[20,26,72]$.

\subsection{CONCLUSION}

Biosurfactants have been proved to become promising agents to replace chemical surfactants because of their flexibility, excellent properties, and applications over chemical surfactants. However, among the drawbacks that render impractical use of biosurfactants in certain industries are the complicated downstream processing to obtain a high yield of biosurfactants with high quality and quantity and lower cost of production. More efforts and studies can be expanded to investigate the strategies on how to enhance biosurfactant yield production, so that biosurfactants can get a place in industrial implementation.

\section{Acknowledgement}

This work was funded by the Ministry of Higher Education, Malaysia under the Research Acculturation Grant Scheme (RAGS). The facilities were supported by Faculty of Bioengineering and Technology and Faculty of Agro-Based Industry, Universiti Malaysia Kelantan, Jeli Campus.

\section{References}

[1] Campos, J. M., Stamford, T. L. M., Sarubbo, L. A., de Luna, J. M., Rufino, R. D., and Banat, I. M. 2013. Microbial Biosurfactants as Additives for Food Industries. Biotechnology Progress. 29(5): 1097-1108.

[2] Lamichhane, S., Krishna, K. C. B., and Sarukkalige, R. 2017. Surfactant-enhanced Remediation of Polycyclic Aromatic Hydrocarbons: A Review. Journal of Environmental Management. 199: 46-61.

[3] Reis, R. S., Pacheco, G. J., Pereira, A. G., and Freire, D. M. G. 2013. Biosurfactants: Production and Applications. R. Chamy, F. Rosenkrantz (Eds.). Biodegrad. - Life Sci., InTechOpen, London. 31-61.

[4] Vecino, X., Cruz, J. M., Moldes, A. B., and Rodrigues, L. R. 2017. Biosurfactants in Cosmetic Formulations: Trends and Challenges. Critical Reviews in Biotechnology. 37(7): 911 923.

[5] Das, P., Mukherjee, S., Sivapathasekaran, C., and Sen, R. 2010. Microbial Surfactants of Marine Origin: Potentials and Prospects. Sen (Ed.). Biosurfactants Adv. Exp. Med. Biol., Landes Bioscience, Texaspp. 88-101.

[6] Hirata, Y., Ryu, M., Oda, Y., Igarashi, K., Nagatsuka, A., Furuta, T., et al. 2009. Novel Characteristics of Sophorolipids, Yeast Glycolipid Biosurfactants, as Biodegradable Low-foaming Surfactants. Journal of Bioscience and Bioengineering. 108(2): 142-146.

[7] Kubicki, S., Bollinger, A., Katzke, N., Jaeger, K. E., Loeschcke, A., and Thies, S. 2019. Marine Biosurfactants: Biosynthesis, Structural Diversity and Biotechnological Applications. Marine Drugs. 17(7): 1-30.

[8] Johnson, P., Pinfield, V. J., Starov, V., and Trybala, A. 2021 Effect of Synthetic Surfactants on the Environment and the Potential for Substitution by Biosurfactants. Advances in Colloid and Interface Science. 288: 102340.

[9] Shekhar, S. and Sundaramanickam, Arumugam
Balasubramaniam, T. 2014. Biosurfactant Producing Microbes and Their Potential Applications: A Review. Environmental Science and Technology. 45(14): 15221554.

[10] Silva, R. C. F. S., Almeida, D. G., Rufino, R. D., Luna, J. M., Santos, V. A., and Sarubbo, L.. 2014. Applications of Biosurfactants in the Petroleum Industry and the Remediation of Oil Spills. International Journal of Molecular Sciences. 15(7): 12523-12542.

[11] Nurfarahin, A. H., Mohamed, M. S., and Phang, L. Y. 2018. Culture Medium Development for Microbial-derived Surfactants Production-An Overview. Molecules. 23(5): 126.

[12] Nitschke, M. and Costa, S. G. V. A. O. 2007. Biosurfactants in Food Industry. Trends in Food Science and Technology. 18(5): 252-259.

[13] Geys, R., Soetaert, W., and Bogaert, I. V. 2014. Biotechnological Opportunities in Biosurfactant Production. Current Opinion in Biotechnology. 30: 66-72.

[14] Marchant, R. and Banat, I. M. 2012. Biosurfactants: A Sustainable Replacement for Chemical Surfactants? Biotechnology Letters. 34(9): 1597-1605.

[15] Liu, J. F., Mbadinga, S. M., Yang, S. Z., Gu, J. D., and Mu, B. Z. 2015. Chemical Structure, Property and Potential Applications of Biosurfactants Produced by Bacillus subtilis in Petroleum Recovery and Spill Mitigation. International Journal of Molecular Sciences. 16(3): 4814-4837.

[16] Vijayakumar, S. and Saravanan, V. 2015. Biosurfactantstypes, Sources and Applications. Research Journal of Microbiology. 10(5): 181-192.

[17] Chen, W. C., Juang, R. S., and Wei, Y. H. 2015. Applications of a lipopeptide Biosurfactant, Surfactin, Produced by Microorganisms. Biochemical Engineering Journal. 103 (November): 158-169.

[18] Fracchia, L., Cavallo, M., Martinotti, M. G., and Banat, I. M. 2012. Biosurfactants and Bioemulsifiers Biomedical and Related Applications - Present Status and Future Potentials. D.N. Ghista (Ed.). Biomed. Sci. Eng. Technol. InTechOpen, Crotiapp. 325-370.

[19] Sarwar, A., Brader, G., Corretto, E., Aleti, G., Abaidullah, M., Sessitsch, A., et al. 2018. Qualitative Analysis of Biosurfactants from Bacillus species Exhibiting Antifungal Activity. PLOS ONE. 13(6): 1-15.

[20] Rodrigues, L., Banat, I. M., Teixeira, J., and Oliveira, R. 2006. Biosurfactants: Potential Applications in Medicine. Journal of Antimicrobial Chemotherapy. 57(4): 609-618.

[21] Karlapudi, A. P., Venkateswarulu, T. C. Tammineedi, J., Kanumuri, L., Ravuru, B. K., Dirisala, V. R., and Kodali, V. P. 2018. Role of Biosurfactants in Bioremediation of Oil Pollution-A Review. Petroleum.

[22] Santos, D. K. F., Rufino, R. D., Luna, J. M., Santos, V. A., and Sarubbo, L. A. 2016. Biosurfactants: Multifunctional Biomolecules of the 21 st Century. International Journal of Molecular Sciences. 17(3): 1-31.

[23] Uzoigwe, C., Burgess, J. G., Ennis, C. J., and Rahman, P. K. S. M. 2015. Bioemulsifiers are not Biosurfactants and Require Different Screening Approaches. Frontiers in Microbiology. 6: 1-6.

[24] Satpute, S. K., Bhuyan, S. S., Pardesi, K. R., Mujumdar, S. S. Dhakephalkar, P. K., Shete, A. M., et al. 2010. Molecular Genetics of Biosurfactant Synthesis in Microorganisms. R. Sen (Ed.). Biosurfactants Adv. Exp. Med. Biol., Landes Bioscience, Texaspp. 14-41.

[25] Mazaheri, A. M. and Tabatabaee, M. S. 2010. Biosurfactants and Their Use in Upgrading Petroleum Vacuum Distillation Residue: A Review. International Journal of Environmental Research. 4(4): 549-572.

[26] Md, F. 2012. Biosurfactant: Production and Application. Journal of Petroleum \& Environmental Biotechnology. 03 (04): 1-5.

[27] Kaczorek, E., Pacholak, A., Zdarta, A., and Smułek, W. 2018. The Impact of Biosurfactants on Microbial Cell Properties Leading to Hydrocarbon Bioavailability Increase. Colloids and Interfaces. 2(3): 35. 
[28] Shete, A. M., Wadhawa, G., Banat, I. M., and Chopade, B. A. 2006. Mapping of Patents on Bioemulsifier and Biosurfactant: A Review. Journal of Scientific and Industrial Research. 65(2): 91-115.

[29] Wen, Y., Cheng, H., Lu, L.-J., Liu, J., Feng, Y., Guan, W., et al. 2010. Analysis of Biological Demulsification Process of Water-in-oil Emulsion by Alcaligenes sp. S-XJ-1. Bioresource Technology. 101 (21): 8315-8322.

[30] Singh, P. and Cameotra, S. S. 2004, Potential Applications of Microbial Surfactants in Biomedical Sciences. Trends in Biotechnology. 22(3): 142-146.

[31] da Rocha Junior, R. B., Meira, H. M., Almeida, D. G., Rufino, R. D., Luna, J. M., Santos, V. A., et al. 2019. Application of a Low-cost Biosurfactant in Heavy Metal Remediation Processes. Biodegradation. 30(4): 215-233.

[32] Nogueira Felix, A. K., Martins, J. J. L., Lima Almeida, J. G., Giro, M. E. A., Cavalcante, K. F., Maciel Melo, V. M., et al. 2019. Purification and Characterization of a Biosurfactant Produced by Bacillus subtilis in Cashew Apple Juice and Its Application in the Remediation of Oil-contaminated Soil. Colloids and Surfaces B: Biointerfaces. 175(November 2018): 256-263.

[33] Dehghan-Noudeh, G., Housaindokht, M., and Bazzaz, B. S. F. 2005. Isolation, Characterization, and Investigation of Surface and Hemolytic Activities of a Lipopeptide Biosurfactant Produced by Bacillus Subtilis ATCC 6633 Journal of Microbiology. 43(3): 272-276.

[34] Fei, D., Zhou, G. W., Yu, Z. Q., Gang, H. Z., Liu, J. F., Yang, S. Z., et al. 2019. Low-Toxic and Nonirritant Biosurfactant Surfactin and its Performances in Detergent Formulations. Journal of Surfactants and Detergents. 23(1): 109-118.

[35] Abha, S. and Singh, C. S. 2012. Hydrocarbon Pollution: Effects on Living Organisms, Remediation of Contaminated Environments, and Effects of Heavy Metals Co-Contamination on Bioremediation. L. Romeo-Zerón (Ed.). Introd. to Enhanc. Oil Recover. Process. Bioremediation Oil-Contaminated Sites, InTech Croatiapp. 185-206.

[36] Sukirta, T. H. and Usharani, M. V. 2013. Production and Qualitative Analysis of Biosurfactant and Biodegradation of the Organophosphate by Nocardia mediterranie. Journal of Bioremediation \& Biodegradation. 04(06): 4-11.

[37] Singh, A. K., Rautela, R., and Cameotra, S. S. 2014. Substrate Dependent In Vitro Antifungal Activity of Bacillus sp strain AR2. Microbial Cell Factories. 13(1): 1-11.

[38] Ehinmitola, E. O., Aransiola, E. F., and Adeagbo, O. P. 2018. Comparative Study of Various Carbon Sources on Rhamnolipid Production. South African Journal of Chemical Engineering. 26: 42-48.

[39] Feng, J. Q., Gang, H. Z., Li, D. S., Liu, J. F., Yang, S. Z., and $\mathrm{MU}$, B. Z. 2019. Characterization of Biosurfactant Lipopeptide and Its Performance Evaluation for Oil-spill Remediation. RSC Advances. 9(17): 9629-9632.

[40] Janek, T., Krasowska, A., Czyznikowska, Z., and Lukaszewicz, M. 2018. Trehalose Lipid Biosurfactant Reduces Adhesion of Microbial Pathogens to Polystyrene and Silicone Surfaces: An Experimental and Computational Approach. Frontiers in Microbiology. 9: 114.

[41] Sabturani, N., Latif, J., Radiman, S., and Hamzah, A. 2016. Spectroscopic Analysis of Rhamnolipid Produced by Pseudomonas Aeruginosa UKMP14T. Malaysian Journal of Analytical Sciences. 20(1): 31-43.

[42] Shah, M. U. H., Sivapragasam, M., Moniruzzaman, M., and Yusup, S. 2016. A Comparison of Recovery Methods of Rhamnolipids Produced by Pseudomonas aeruginosa. Procedia Engineering. 148: 494-500.

[43] Weber, A. and Zeiner, T. 2015. Purification of Biosurfactants. F. V.-S. Kosaric, N. (Ed.). Biosurfactants, CRC Press. 129-152.

[44] Invally, K., Sancheti, A., and Ju, L.. 2019. A New Approach for Downstream Purification of Rhamnolipid Biosurfactants. Food and Bioproducts Processing. 114: 122-131.

[45] Inès, M., Dhouha, G., and Inès, M. \& Dhouha, G. 2015.
Lipopeptide Surfactants: Production, Recovery and Pore Forming Capacity. Peptides. 71: 100-112.

[46] Varjani, S. J. and Upasani, V. N. 2017. Critical Review on Biosurfactant Analysis, Purification and Characterization Using Rhamnolipid as a Model Biosurfactant. Bioresource Technology. 232: 389-397.

[47] Satpute, S. K., Banpurkar, A. G., Dhakephalkar, P. K., Banat, I. M., and Chopade, B. A. 2010. Methods for investigating Biosurfactants and Bioemulsifiers: A Review. Critical Reviews in Biotechnology. 30(2): 127-144.

[48] You, Z., Xu, H., Zhang, S., Kim, H., Chiang, P. C., Yun, W., et al. 2018. Comparison of Petroleum Hydrocarbons Degradation by Klebsiella Pneumoniae and Pseudomonas aeruginosa. Applied Sciences. 8(12): 1-19.

[49] Abdul Razak, N. N., Abdullah, N., Awang Biak, D. R., and Mohd Yatim, A. R. 2015. Solvent-less Approach for the Recovery of Palm-based Sophorolipids Biosurfactant Via Salting-out Method. Journal of Oil Palm Research. 27(2): 181-189.

[50] Banat, I. M., Franzetti, A., Gandolfi, I., Bestetti, G., Martinotti, G., Fracchia, L., et al. 2010. Microbial Biosurfactants Production, Applications and Future Potential. Applied Microbiology and Biotechnology. 87(2): 427-444.

[51] Najmi, Z., Ebrahimipour, G., Franzetti, A., and Banat, I. M. 2018. In situ Downstream Strategies for Cost-effective Bio/surfactant Recovery. Biotechnology and Applied Biochemistry. 65(4): 523-532.

[52] Bages-Estopa, S., White, D. A., Winterburn, J. B., Webb, C., and Martin, P. J. 2018. Production and Separation of a Trehalolipid Biosurfactant. Biochemical Engineering Journal. 139: 85-94.

[53] Mulligan, C. N. and Gibbsb, B. F. 1990. Recovery of Biosurfactants by Ultrafiltration. Journal of Chemical Technology and Biotechnology. 47: 23-29.

[54] Wahib, Z. M., Mahmood, N. N., and Khudhaier, S. R. 2020 Extraction of Biosurfactant from Pseudomonas aeruginosa and its Effects on Some Pathogenic Bacteria. 20(2): 67006704.

[55] Zhang, S., WU, W., Li, D., and Zheng, Q. 2015. Separation and Purification of Six Biosurfactant Rhamnolipids by Highspeed Countercurrent Chromatography Utilizing Novel Solvent Selection Method. Separation Science and Technology (Philadelphia). 51 (4): 673-680.

[56] Sonawdekar, S. 2012. Bioremediation: A Boon to Hydrocarbon Degradation. International Journal of Environmental Sciences. 2(4): 2408-2424.

[57] Bustamante, M., Durán, N., and Diez, M. C. 2012 Biosurfactants are Useful Tools for the Bioremediation of Contaminated Soil: A Review. Journal of Soil Science and Plant Nutrition. 12(4): 667-687.

[58] Maletic, S., Dalmacija, B., and Roncevic, S. 2013. Petroleum Hydrocarbon Biodegradability in Soil Implications for Bioremediation. V. Kutcherov (Ed.). Hydrocarbon, IntechOpen. 43-64.

[59] Souza, E. C., Vessoni-Penna, T. C., and Oliveira, R. P. S. 2014. Biosurfactant-enhanced Hydrocarbon Bioremediation: An Overview. International Biodeterioration and Biodegradation. 89: 88-94.

[60] Franzetti, A., Bestetti, G., Caredda, P., La Colla, P., and Tamburini, E. 2008. Surface-active Compounds and their Role in the Access to Hydrocarbons in Gordonia Strains. FEMS Microbiology Ecology. 63(2): 238-248.

[61] Hamzah, A., Rabu, A., Azmy, R. F. H. R., and Yussoff, N. A. 2010. Isolation and Characterization of Bacteria Degrading Sumandak and South Angsi Oils. Sains Malaysiana. 39(2): 161-168.

[62] Janaki, S., Thenmozhi, S., and Muthumari, R. 2016. A Study on Hydrocarbon Degradation by Biosurfactant Producing Bacillus Cereus in Oil Contaminated Soil Samples. International Journal of Life-Sciences Scientific Research. 2(4): 324-332.

[63] Freitas, B. G., Brito, J. G. M., Brasileiro, P. P. F., Rufino, R. D. Luna, J. M., Santos, V. A., et al. 2016. Formulation of a 
Commercial Biosurfactant for Application as a Dispersant of Petroleum and by-products Spilled in Oceans. Frontiers in Microbiology. 7(OCT): 1-9.

[64] Sylvester, O., Onyekonwu, M., and Okpokwasili, G. 2019. Isolation and Screening of Hydrocarbon Utilizing Bacteria for Biosurfactant Production: Application for Enhanced oil Recovery. Soc. Pet. Eng. - SPE Niger. Annu. Int. Conf. Exhib. 2019, NAIC 2019

[65] Wong, S. F., Lim, J. S., and Dol, S. S. 2015. Crude Oil Emulsion: A Review on Formation, Classification and Stability of Water-in-Oil Emulsions. Journal of Petroleum Science and Engineering. 135: 498-504.

[66] Fink, J. 2015 Demulsifiers. Pet. Eng. Guid. to Oil F. Chem. Fluids. 2nd ed., Gulf Professional Publishing. 787-808.

[67] Sabati, H. and Motamedi, H. 2020. Efficient Separation of Water-in-oil Petroleum Emulsions by a Newly Isolated Biodemulsifier Producing Bacterium, Delftia sp. strain HS3. Environmental and Experimental Biology. 18(2): 129-134.

[68] Bafghi, M. K. and Fazaelipoor, M. H. 2012. Application of Rhamnolipid in the Formulation of a Detergent. Journal of Surfactants and Detergents. 15(6): 679-684.
[69] Perfumo, A., Banat, I. M., and Marchant, R. 2018. Going Green and Cold: Biosurfactants from Low-temperature Environments to Biotechnology Applications. Trends in Biotechnology. 36(3): 277-289.

[70] Zarinviarsagh, M., Ebrahimipour, G., and Sadeghi, H. 2017. Lipase and Biosurfactant from Ochrobactrum Intermedium Strain MZV101 Isolated by Washing Powder for Detergent Application. Lipids in Health and Disease. 16(1): 1-13.

[71] Tadros, T. F. 2005. Applied Surfactants: Principles and Applications. Wiley-VCH, Germany.

[72] Cameotra, S. S., Makkar, R. S., Kaur, J., and Mehta, S. K. 2010. Synthesis of Biosurfactants and Their Advantages to Microorganisms and Mankind. R. Sen (Ed.). Biosurfactants Adv. Exp. Med. Biol., Landes Bioscience, Texaspp. 261-280.

[73] Bhat, R., Dayamani, K.J., Hathwar, S., Hedge, R., and Kush, A. 2015. Exploration on Production of Rhamnolipid Biosurfactants Using Native Pseudomonas aeruginosa Strains. Journal of BioScience and Biotechnology. 4(2): 157-166. 